Oppsummering av landsomfattende tilsyn i 2007 med forsvarlighet og kvalitet i akuttmottak i somatisk spesialisthelsetjeneste

"MENS VI VENTER ..."

- forsvarlig pasientbehandling i akuttmottakene?

\title{
HELSET LSYNET
}


Rapport fra Helsetilsynet 2/2008

"MENS VI VENTER ..." - forsvarlig pasientbehandling i akuttmottakene ?

Oppsummering av landsomfattende tilsyn i 2007 med forsvarlighet og kvalitet i akuttmottak i somatisk spesialisthelsetjeneste.

Februar 2008

ISSN: 1503-4798 (elektronisk utgave)

Denne publikasjonen finnes på Helsetilsynets nettsted www.helsetilsynet.no

Design: Gazette

Trykk og elektronisk versjon: Lobo Media AS

Statens helsetilsyn

Postboks 8128 Dep, NO-0032 OSLO, Norway

Telefon: 21529900

Faks: 21529999

E-post: postmottak@helsetilsynet.no 


\section{Innholdsfortegnelse}

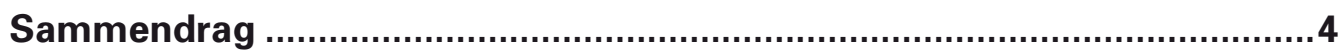

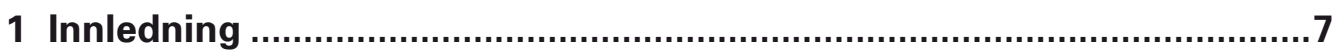

1.1 Akuttmottaket - hvem kommer dit og hva skjer der ? ..............................

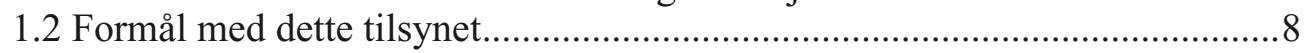

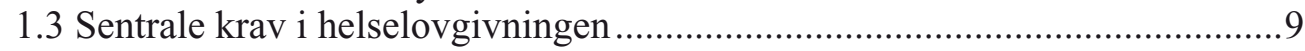

2 Metode og gjennomføring...................................................................11

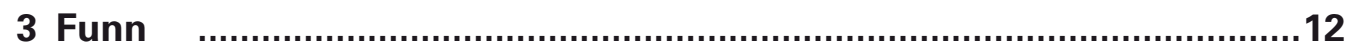

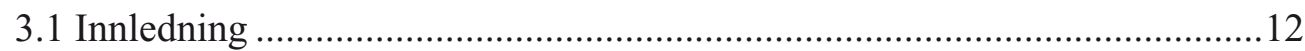

3.2 Forsvarlig pasientbehandling når det er mange pasienter i

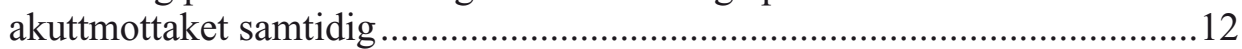

3.2.1 Mottak, prioritering og overvåking av pasienter...................................12

3.2.2 Undersøkelse og diagnostikk ............................................................14

3.2.3 Observasjon og medisinsk oppfølging av pasienter i ventetid før

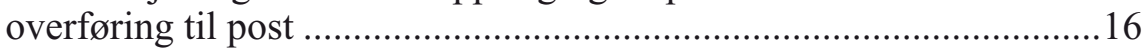

3.3 Ledelse, organisering og styring som forutsetning for forsvarlig

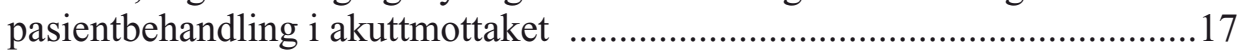

3.3.1 Koordinering og styring for å sikre forsvarlig pasientbehandling ........18

3.3.2 Rutiner og praksis for kommunikasjon og samhandling mellom

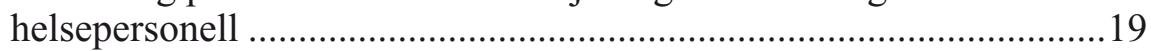

3.3.3 Kompetansebygging og kompetansestyring ..................................20

3.3.4 Om å lære av svikt og uønskede hendelser for å sikre forsvarlig pasientbehandling

4 Statens helsetilsyns vurdering..

4.1 Organisering, koordinering og styring for å sikre forsvarlig pasientbehandling.

4.2 Forsvarlig prioritering, overvåkning og undersøkelse av pasienter..............24

4.3 Kompetansebygging og kompetansestyring for å sikre forsvarlig pasientbehandling.

5 Statens helsetilsyns oppsummering og anbefalinger

Čoahkkáigeassu.

English summary 


\section{Sammendrag}

Helsetilsynet i fylkene gjennomførte i 2007 landsomfattende tilsyn med forsvarlighet og kvalitet i 27 akuttmottak i somatisk spesialisthelsetjeneste. Statens helsetilsyn har funnet et totalbilde som viser at mangelfull styring og ledelse preger hverdagen i disse akuttmottakene. Etter vår vurdering gir dette til tider uforsvarlig pasientbehandling.

Ledelsen i helseforetaket har ansvar for å sikre at daglige arbeidsoppgaver blir planlagt, organisert, utført og forbedret i samsvar med krav i helselovgivningen. Det er en forutsetning for at mottak, prioritering, undersøkelse, diagnostisering, overvåking og behandling av pasienter i akuttmottak skal være faglig forsvarlig. Hovedmålet med dette landsomfattende tilsynet var å undersøke om og hvordan helseforetakene ivaretar ansvaret sitt. For å undersøke dette nærmere ble pasienter med uavklarte diagnoser valgt som eksempel eller "veivisere". Ofte dreier det seg om eldre pasienter med svikt i flere organer og ulike typer symptomer samtidig, som for eksempel ryggsmerter, magesmerter, bevisstløshet, uklarhet, kvalme. På mange måter er disse pasientene en større utfordring for akuttmottaket, både faglig og organisatorisk, enn for eksempel pasienter med kompliserte skader eller ved mistanke om hjerteinfarkt der behandlingsforløpet er fastlagt på forhånd med rask overføring til relevante avdelinger i sykehuset.

Det er ledelsens ansvar å sørge for at virksomheten har rutiner for å sikre ens praksis når pasientene kommer inn døra til akuttmottaket, at pasientene systematisk blir fanget opp, registrert og vurdert i prioriteringskøen og at de som trenger medisinsk hjelp raskest, får det. Flere av virksomhetene i dette tilsynet manglet et forsvarlig system for å prioritere pasientene når de kommer til akuttmottaket. Blant annet fant vi at leger og sykepleiere ikke hadde ens oppfatning av hvor raskt undersøkelse og diagnostisering av pasientene måtte skje, og dermed ikke var enige om hvem som trenger medisinsk hjelp først.

I mer enn halvparten av akuttmottakene er det usikkert om pasientene får faglig forsvarlig undersøkelse og diagnostisering. I mange av virksomhetene fant vi eksempler på at ved stor trafikk i akuttmottaket må pasienter med uavklarte tilstander vente flere timer på legens undersøkelse og diagnostisering. Lang ventetid kan øke faren for at pasientens sykdomstilstand blir forverret, at pasienten får for lite væsketilførsel, ikke får nødvendig smertelindring $\mathrm{og}$ blir forvirret. Det vesentlige er at pasientene blir observert og fulgt opp mens de venter, at personellet har relevant kompetanse og at hensiktsmessige tiltak blir satt $i$ gang i tide. Vi fant også at $i$ mange tilfeller blir ikke pasientene godt nok fulgt opp i ventetiden. Dersom rutiner og praksis ikke er på plass, kan personalet komme til å overse alvorlige sykdomsbilder, og det er fare for at pasientbehandlingen ikke kommer i gang til rett tid.

Forsvarlig pasientbehandling henger 
nøye sammen med kompetanse.

Personalet som skal gi helsetjenester i akuttmottaket, må ha relevant og riktig kompetanse til å gjøre medisinskfaglige avveininger og vurderinger som til tider kan være komplekse.

Funn i dette tilsynet gir grunn til bekymring for om ledelsen i helseforetakene gjør nok for å styre personal- og kompetanseressursene slik at pasientbehandlingen i akuttmottaket er faglig forsvarlig i travle perioder. I de fleste akuttmottakene var det turnusleger eller nye assistentleger som gjorde de første foreløpige legeundersøkelsene. Når nye leger med varierende kompetanse og erfaring er første lege som møter pasienten, må virksomheten sikre kompetansen ved systematisk opplæring i oppgaver og rutiner i akuttmottaket, og ved å ha fleksible og robuste ordninger med lav terskel for å tilkalle mer erfarne leger. Dette var ikke på plass i flere av akuttmottakene.

Gjennom rutiner og innarbeidet praksis må det være tydelig for alle som arbeider i akuttmottaket, hvem som skal tilkalle hjelp når det er behov for høyere og mer spesialisert kompetanse. Det må også være klart for alle hvem som skal tilkalle ekstra og nødvendig personell ved aktivitetstopper og hverdagskriser, enten det skyldes stor pågang av pasienter eller opphopning av pasienter som venter på overføring til andre avdelinger i sykehuset. I flere av akuttmottakene hadde ikke personalet ens oppfatning av i hvilke situasjoner ekstra ressurser skal tilkalles, og hvem som er ansvarlig for å tilkalle ekstra ressurser. Mye tyder også på at terskelen for å tilkalle andre leger med mer erfaring og kompetanse, er høy i flere av akuttmottakene i dette tilsynet. I de fleste virksomhetene ser det ikke ut til å være vanlig praksis å bruke helseforetakets samlede faglige ressurser når det er behov for å sikre pasientene forsvarlig undersøkelse og behandling i akuttmottaket. Det bekymrer Statens helsetilsyn.

At akuttmottaket er selve inngangsporten til sykehuset, gir særskilte styringsmessige og driftsmessige utfordringer. Forsvarlig pasientbehandling må sikres gjennom samhandling mellom akuttmottaket og de øvrige kliniske avdelingene i sykehuset. For eksempel er legene som yter helsetjenester i akuttmottaket, vanligvis organisert i medisinske og kirurgiske avdelinger, og ikke i akuttmottaket. Dette forsterker behovet for tydelige styrings- og rapporteringslinjer. I 24 av 27 helseforetak som er omfattet av dette tilsynet, arbeider ikke ledelsen tilstrekkelig systematisk og målrettet for å sikre forsvarlig drift og pasientbehandling $i$ akuttmottakene, slik helselovgivningen pålegger. Det er uakseptabelt slik Statens helsetilsyn ser det.

I mange av helseforetakene etterspurte ikke ledelsen systematisk hva som skjer i akuttmottakene. For eksempel brukte ikke ledelsen aktivitetstall fra akuttmottaket til å overvåke driften og gjøre seg opp en mening om hva som kan være kritiske trinn i arbeidsprosessene og oppgaveløsningen. Ledelsen brukte heller ikke systematiske oversikter over pasientstrømmen og ventetider for å evaluere om medisinsk diagnose og undersøkelse blir gjennomført innen forsvarlig tid og til å identifisere kritiske trinn i pasientflyt og behandlingsforløp. Det er en del av hverdagen i akuttmottaket at det i perioder oppstår flaskehalser og hoper seg opp med pasienter. Flere av virksomhetene manglet systematisk oversikt over og vurderinger av hvilke konsekvenser dette kan ha for forsvarlig pasientbehandling. Samlet sett betyr dette at ledelsen har dårlig oversikt over driften i akuttmottakene og at den ikke gjør systematiske risikovurderinger for å sikre forsvarlig planlegging og styring av medisinskfaglig og sykepleiefaglig bemanning i akuttmottaket. Dermed har ikke ledelsen grunnlag for å sette i gang målrettede tiltak som kan rette opp forholdene, redusere faren for svikt og bedre pasientsikkerheten.

Tilsynet avdekket også andre mangler i helseforetakenes kvalitetsstyringssystemer. Det er for eksempel bekymringsfullt at rutiner og prosedyrer for kjerneoppgaver og sentrale arbeidsprosesser er lite kjent og dermed heller ikke fulgt av personalet i mange av akuttmottakene i dette tilsynet. Flere av akuttmottakene har heller ikke et velfungerende 
avviksbehandlingssystem. Dette dreier seg om å ha innarbeidet rutiner og praksis blant de ansatte for å melde avvik knyttet til akuttmottakets aktivitets- og resultatmål, og om at ledelsen ikke bruker avviksmeldingene på en systematisk måte i sin gjennomgang av virksomheten med tanke på forbedring. Det er ikke bare de alvorlige pasientskadene som skal meldes eller tas opp, men også svikt i daglige rutiner og avvik fra fastsatte aktivitetsmål for virksomheten. For å lære av uønskede hendelser og sikre forsvarlig tjenesteyting må systematisk avviksbehandling være en prioritert oppgave for ledelsen.

Det er i et akuttmottak, som i sosial- og helsetjenesten for øvrig, en nær sammenheng mellom faglige og styringsmessige utfordringer. Vi har i dette tilsynet avdekket forhold som illustrerer hvordan tjenesteytingen i akuttmottakene blir satt på strekk når ledelsen ikke arbeider tilstrekkelig systematisk og målrettet for å sikre forsvarlig pasientbehandling. Det kan ikke Statens helsetilsyn akseptere. At det befinner seg mange pasienter i akuttmottaket samtidig er et hverdagsfenomen, ikke en unntakstilstand. I de fleste av akuttmottakene henger for mye av den daglige driften på at kompetente enkeltpersoner i akuttmottaket "bretter opp ermene" og strekker seg svært langt for å løse kinkige situasjoner, hverdagskriser og flaskehalsproblematikk. For helsepersonellet i akuttmottaket betyr dette unødvendig stor belastning og slitasje, som i sin tur kan få uønskede konsekvenser for behandlingen av pasientene. Det synes å være et mønster at ad hocløsninger snarere enn systematisk styring redder pressede situasjoner fra å utvikle seg til uønskede hendelser og svikt. Samlet sett gjør dette at faren for svikt er så stor at kravet til forsvarlig drift i akuttmottakene ikke kan anses å være oppfylt.

Statens helsetilsyn har gjennom dette tilsynet avdekket at $\mathrm{i}$ perioder når det hoper seg opp med mange pasienter i akuttmottaket samtidig, som enten venter på lege eller på å bli overført til en annen avdeling i sykehuset, er det kompetente enkeltpersoner i akuttmottakene som "bretter opp ermene", improviserer og finner ad hoc-løsninger og redder pressede situasjoner fra å utvikle seg til uønskede hendelser og svikt.

Nå er det ledelsen i helseforetakene som må "brette opp ermene" og sette i verk tiltak som gir mer systematisk og målrettet styring av driften i akuttmottakene, og dermed sikre forsvarlig pasientbehandling til en hver tid. 


\section{Innledning}

\subsection{Akuttmottaket - hvem kommer dit og hva skjer der?}

Sykehusene har etter spesialisthelsetjenesteloven plikt til å ta i mot, undersøke og eventuelt sette i gang behandling av pasienter med behov for innleggelse i sykehus. Akuttmottakene er inngangsporten til sykehuset. Etter at akuttmottaket har gjort de første undersøkelsene og pasientene har fătt en foreløpig diagnose, skal de overføres til den av sykehusets avdelinger som kan gi mer spesialisert behandling. Øyeblikkelig hjelp-innleggelse i sykehus er definert som: "Henvisning til eller mottak av pasient $i$ helseinstitusjon som har behov for umiddelbar eller snarlig undersøkelse, behandling eller pleie. Gjelder pasienter med antatt hjelpebehov innen 24 timer fra første kontakt med helsetjenesten." (NOU 1998:9) ${ }^{1}$

Øyeblikkelig hjelp er en samlebetegnelse for pasienter som kommer til sykehuset på kort varsel, og som har behov for medisinsk hjelp og behandling innen ett døgn etter at de har kontaktet helsetjenesten første gang. Pasientgruppen, som utgjør flertallet av innleggelser i norske sykehus, er svært differensiert. Det kan være pasienter med livstruende sykdom som krever umiddelbar behandling, men også pasienter med mer uklare sykdomsbilder og diagnoser som trenger undersøkelse og observasjon uten at akutt behandling er nødvendig.

Pasienter som har behov for øyeblikke- lig hjelp, kan komme til akuttmottaket via tre veier.

For det første kan pasientene være henvist fra fastlegen eller legevakten. Dette er pasienter som er meldt til sykehuset på forhånd, og personellet $\mathrm{i}$ akuttmottaket er forberedt og venter på at de skal komme. Når de kommer, er de undersøkt av lege i primærhelsetjenesten som vanligvis har stilt en foreløpig diagnose i samarbeid med vakthavende lege på sykehuset. Ut fra den informasjonen de sitter med vil vaktteamet $i$ akuttmottaket ha mulighet til å planlegge mottak og forløp med sikte på å stille diagnosen raskt og sette i gang behandling.

Pasienter med akutt sykdom eller skade kan også bli brakt til akuttmottaket gjennom ambulansetjenesten. Det kan være pasienter med akutte brystsmerter, plutselig bevissthetstap eller de har vært utsatt for ulykker, og det foreligger mistanke om større skader. Som oftest er ikke disse pasientene undersøkt av lege, men er meldt til akuttmottaket av ambulansepersonellet som har gitt en problembeskrivelse eller stilt en foreløpig diagnose. Også disse pasientene vil vaktteamet være forberedt på, men ankomsttidspunkt er av og til noe usikkert. Mange som kommer til akuttmottaket på denne måten, er kritisk syke, og det er nødvendig med rask diagnose og umiddelbar igangsetting av behandling. Det vil være avgjørende at kvalifisert personell er til stede når pasienten kommer. 
Videre kan pasienter komme uanmeldt og direkte til akuttmottaket uten å ha vært i kontakt med helsepersonell på forhånd. Mange av disse kommer med tilstander som kunne vært tatt hånd om av legevakten. De kan komme direkte fordi de ikke har kjennskap til hvor legevakten er, det er lang kø på legevakten eller det er mistanke om akutt, alvorlig sykdom eller skade som gjør at pasienten bringes direkte til sykehuset. Den største utfordringen med denne pasientgruppen er å skille ut de som er alvorlig syke med tanke på rask diagnose og behandling. En del kan få generell informasjon om legevakten og bli bedt om å henvende seg dit, noe som til en viss grad kan styres ved at akuttmottaket samarbeider med legevakten. Dersom pågangen via denne veien er stor, kan det få negative følger for akuttmottakets behandling av de mest alvorlig syke pasientene.

Avhengig av hvordan foretaket har organisert mottaket av pasienter, kan det også komme såkalte elektive pasienter til akuttmottaket. Dette er pasienter som ikke trenger øyeblikkelig hjelp, men som kommer til sykehuset for en planlagt innleggelse og skrives inn via akuttmottaket. Flere sykehus er imidlertid organisert slik at mottak av elektive pasienter skjer direkte i aktuell avdeling.

Ved stor pågang av øyeblikkelig hjelppasienter, kan planlagte innleggelser skape en opphopning av pasienter i akuttmottakets lokaler og føre til at det blir vanskelig for personellet å holde oversikt over de kritiske syke pasientene, dermed oppta kapasitet og ressurser for akuttmottakets personell. Når disse pasientene kommer til akuttmottaket, kan sykepleiefaglige ressurser bli opptatt med å sluse disse videre inn i sykehuset. I de akuttmottakene hvor denne pasientgruppen også blir undersøkt av lege i akuttmottaket, øker risikoen for mangel på oversikt ved stor pågang av øyeblikkelig hjelp.

Sykehusenes akuttmottak illustrerer mange generelle problemstillinger ved organisering og drift av spesialisthelsetjenester. Ledelse, organisering og styring av akuttmottak byr på flere faglige og styringsmessige utfordringer.
Akuttmottaket har ulik organisatorisk plassering i sykehusene, og kan være en egen avdeling innenfor en akuttmedisinsk eller medisinsk klinikk/ divisjon, eller også en seksjon i en avdeling. Mange steder er det fast personell tilknyttet akuttmottaket, hovedsaklig sykepleiere, og eventuelt hjelpepleiere og helsesekretærer, mens leger og eventuelt annet personell oftest blir hentet inn fra andre avdelinger, klinikker eller divisjoner. Det betyr at flere avdelinger i sykehuset er involvert i tjenesteytingen i akuttmottaket; noe som krever samhandling på tvers av avdelinger både på ulike ledelsesnivåer og på operativt nivå.

Uansett organisatorisk plassering vil akuttmottaket også ha særlige utfordringer knyttet til funksjonen som inngangsport til sykehuset. Som allerede beskrevet gjelder de fleste henvendelser til akuttmottaket akutte problemstillinger som enten krever poliklinisk behandling eller innleggelse i sykehus. Dette stiller særlige krav til kommunikasjon, samhandling og fleksibilitet, særlig når det er stor pågang av pasienter, og det kan være behov for å sette inn ekstra ressurser og sette i gang ekstraordinære tiltak.

\subsection{Formål med dette tilsynet}

Ledelsen i helseforetaket har ansvar for å sikre at daglige arbeidsoppgaver blir planlagt, organisert, utført og forbedret i samsvar med krav i helselovgivningen. Det er en forutsetning at myndighetskravene i helselovgivningen blir etterlevd for at mottak, prioritering, undersøkelse, diagnostisering, overvåking $\mathrm{og}$ behandling av pasienter i akuttmottak skal være faglig forsvarlig. Hovedmålet med dette landsomfattende tilsynet var å undersøke om og hvordan helseforetakene ivaretok ansvaret sitt.

En del av akuttmottakets virksomhet er knyttet til store og dramatiske hendelser, som for eksempel store trafikkulykker. For de fleste større sykehus vil slike hendelser utløse særlige innsatsgrupper som arbeider etter standardiserte retningslinjer. Etter Statens helsetilsyns vurdering synes dette å være 
såpass godt ivaretatt at det ikke representerer en stor organisatorisk risiko, og denne type hendelser var derfor ikke en del av dette tilsynet. Derimot rettet tilsynet oppmerksomheten mot daglige situasjoner med tilfeldig opphopning av pasienter og ekstra belastning som følge av dette, altså hvordan "hverdagskrisene" og samtidighetskonfliktene ble håndtert.

For å undersøke dette nærmere ble pasienter med uavklarte diagnoser valgt som eksempel eller "veivisere". Dette er ofte eldre pasienter med svikt i flere organer og ulike typer symptomer samtidig, som for eksempel ryggsmerter, magesmerter, bevisstløshet, uklarhet og kvalme. På mange måter er disse pasientene en større utfordring for akuttmottaket, både faglig og organisatorisk, enn for eksempel pasienter med kompliserte skader, eller ved mistanke om hjerteinfarkt der behandlingsforløpet er fastlagt på forhånd med rask overføring til relevante avdelinger i sykehuset.

Som beskrevet i forrige kapittel er sykehusene store og kompliserte organisatoriske enheter, og akuttmottakene illustrerer mange aktuelle problemstillinger ved organisering og drift av spesialisthelsetjenester. Tilsynet har rettet fokus mot de spesielle utfordringene som fremkommer i en slik virksomhet.

Valg av tema og område for tilsynet er gjort på grunnlag av vurdering av risiko og sårbarhet $i$ akuttmottaket. Gjennom en slik risikovurdering har vi systematisk gjennomgått og analysert ulike arbeidsprosesser og aktiviteter. Som hjelp i risikovurderingen har vi benyttet den kunnskap, oversikt og de erfaringene som er tilgjengelige, og valgt ut tema på de områder der det er størst risiko for svikt og der svikten kan ha alvorlige konsekvenser for pasientene.

Som forberedelse til tilsynet har vi gjennomgått informasjon fra tilsynssaker, meldinger etter spesialisthelsetjenestelovens § 3-3 Meldeplikt til Helsetilsynet i fylket og andre tilsynserfaringer. Vi har også hatt møter med relevante fagmiljøer og med Riksrevisjonen som i 2005 undersøkte akuttmedisinsk beredskap i spesialisthelse- tjeneste 2 . Den undersøkelsen omfattet blant annet 34 av de 54 akuttmottakene i somatisk spesialisthelsetjeneste i landet. Blant annet viste den at pasientene $\mathrm{i}$ akuttmottaket ofte må vente lenge før de blir vurdert av lege og at de deretter må vente for å få plass på sengepost $\mathrm{i}$ andre avdelinger. Riksrevisjonens undersøkelse avdekket også at foretaksledelsen ikke etterspør styringsinformasjon som kan fortelle noe om daglig drift, aktivitet og kvalitet i akuttmottakene.

Tilsynet omfattet hele tidsperioden fra pasienten ankommer akuttmottaket til pasienten forlater akuttmottaket og tre områder ble plukket ut:

- mottak og prioritering av pasienter i akuttmottaket

- undersøkelse og diagnostisering av pasienter

- observasjon og oppfølging av pasienter i ventetid før overføring til post.

\subsection{Sentrale krav i helselov- givningen}

Både offentlige og private sykehus har plikt til å straks motta en pasient når det etter de opplysninger som foreligger, antas at den hjelp institusjonen kan gi er påtrengende nødvendig. Denne plikter følger av lov om spesialisthelsetjenesten m.m. § 3-1, og omtales gjerne som plikten til å yte øyeblikkelig hjelp. Plikten innebærer mottak, undersøkelse og eventuelt nødvendig behandling av øyeblikkelig hjelp-pasienter så langt det er mulig ut fra tilgjengelig bemanning, kompetanse og utstyr, men er ikke et krav til institusjoner om å organisere akuttberedskap.

Det er de regionale helseforetakene som skal sørge for at det innen helseregionen tilbys spesialisthelsetjeneste, herunder blant annet sykehustjenester og akuttmedisinsk beredskap, jfr. lov om spesialisthelsetjeneste m.m. $\S 2-1 a$.

Tilsynet har vært rettet mot offentlige helseforetak med organisert akuttmedisinsk beredskap, det vil si sykehus med akuttmottak. 
Krav om forsvarlig mottak, prioritering, undersøkelse, diagnostisering, overvåkning og behandling av pasienter i akuttmottak følger av lov om spesialisthelsetjeneste m.m $\S 2-2$, hvor det fremgår at helsetjenester som tilbys eller ytes skal være "forsvarlige".

At helsetjeneste som tilbys eller ytes skal være forsvarlig, er et krav til at innholdet $\mathrm{i}$ tjenesten skal være $\mathrm{i}$ samsvar med en standard. Denne standarden vil kunne variere i forhold til hvilke type tjenester det dreier seg om.

I Helse- og omsorgsdepartementets rundskriv I-59/2000, er bestemmelsen utdypet i merknad:

"Plikten til forsvarlighet gjelder på alle ledelsesnivå. Den innebcerer at funksjoner som planlegging, utbygging, organisering, drift og vedlikehold av helsetjenester må innrettes på måter som gjør at forsvarlighetsnormen kan etterleves. Eiere og ledere har et generelt ansvar for at driften gjennomføres innen lovfastsatte rammer. Det er derfor eiere og ledere som har ansvar for à gjennomføre de tiltak som er nødvendige for at de tjenestene som tilbys eller ytes er forvarlige.

For å sikre at innholdet $i$ tjenesten er forvarlig, må ulike komponenter vare tilstede. Eier og ledere må blant annet sørge for at utstyret er $i$ orden, at personale har tilstrekkelig kompetanse, at ansvarsforhold er avklart, at ansvarlige vaktordninger er etablert m.v. I utgangspunktet kan forskjellige organisatoriske løsninger velges dersom minstestandarden blir overholdt".

Sykehusene har videre plikt til å "etablere et internkontrollsystem for virksomheten og sørge for at virksomhet og tjenester planlegges, utføres og vedlikeholdes i samsvar med krav fastsatt i eller i medhold av lover og forskrifter", jfr. lov om statlig tilsyn med helsetjenesten § 3. Denne plikten er nærmere regulert i forskrift om internkontroll $i$ sosial-og helsetjenesten.
I forkant av tilsynet utarbeidet Statens helsetilsyn en veileder for gjennomføringen av tilsynet, som blant annet klargjør hva som kan anses som forvarlig mottak, prioritering, undersøkelse, diagnostisering, overvåkning og behandling av pasienter i akuttmottaket i henhold til lov om spesialisthelsetjeneste m.m. $\S 2-2$; og videre de gjennomgående utfordringene knyttet til kravene til ledelse, organisering og styring av akuttmottak, etter bestemmelsene i internkontrollforskriften. Disse kravene utgjorde sammen et sett revisjonskriterier som Helsetilsynet i fylkene arbeidet etter ved gjennomføringen av tilsynet. Kriteriene ble beskrevet og klargjort slik at det skulle være tydelig og konkret hva Helsetilsynet i fylkene måtte undersøke for å kunne vurdere hvordan sykehusene håndterte faglige og styringsmessige utfordringer i akuttmottaket, og trekke konklusjoner i forhold til om sykehusene etterlevde kravene $\mathrm{i}$ helselovgivningen.

Hvilke kriterier som ble lagt til grunn, vil fremgå av beskrivelsen av de ulike funnene. 


\section{Metode og gjennomføring}

Helsetilsynet i fylkene har utført dette landsomfattende tilsynet på oppdrag fra Statens helsetilsyn. Det er gjennomført som systemrevisjon. Ved systemrevisjon blir informasjon innhentet på en systematisk måte gjennom gransking av dokumenter, ved intervju, ved befaringer i virksomheten og ved verifikasjoner. Verifikasjoner er stikkprøver for å undersøke om prosedyrer, instrukser og rutiner blir fulgt i praksis og om de fysiske forholdene tilfredsstiller myndighetskravene.

Formålet med denne type tilsyn er å få bekreftet at virksomhetene gjennom systematisk styring og ledelse etterlever ulike krav i helselovgivningen.

Tilsynet ble gjennomført av fem regionale tilsynslag - ett i hver helseregion. Tilsynslagene var satt sammen av medarbeidere med helsefaglig og juridisk kompetanse fra Helsetilsynet i fylkene.

I etterkant av dette landsomfattende tilsynet har de regionale tilsynslagene også utarbeidet regionale rapporter som summerer opp funnene på regionnivå. Disse funnene er lagt fram for de regionale helseforetakene i møte. Både rapportene fra de enkelte tilsyn og de regionale samlerapportene er tilgjengelige på www.helsetilsynet.no. Der ligger også denne oppsummeringsrapporten.

Når Helsetilsynet i fylket valgte ut hvilke akuttmottak det skulle føres tilsyn med, ble det dels gjort ut i fra lokal kunnskap og risikovurdering, og dels ut i fra andre hensyn, som for ek- sempel hvor lenge det var siden forrige tilsyn i virksomheten og ulike sentrale føringer. Utvalget av virksomheter er derfor ikke tilfeldig, men er en risikobasert og strategisk utvalgsmetode som innebærer at vi sannsynligvis finner mer svikt enn om utvalget av virksomheter var tilfeldig. Vi kan slik sett ikke være sikre på at det bildet som kommer fram i tilsynsrapportene er representativt for forholdene i alle akuttmottak i norske sykehus. Statens helsetilsyn mener likevel at rapportene gir et godt bilde av en del utfordringer denne delen av helsetjenesten står overfor.

Denne rapporten bygger på resultat fra de 27 gjennomførte tilsynene. De viktigste funn og utviklingstrekk som Statens helsetilsyn mener er relevante i nasjonal sammenheng, er oppsummerte og blir presentert i kapittel 3 . 


\section{Funn}

\subsection{Innledning}

Dette kapittelet bygger på en samlet gjennomgang og sammenstilling av rapportene som Helsetilsynet i fylkene har utarbeidet etter hvert enkelt tilsyn. Revisjonsrapportene beskriver faktiske forhold tilsynsmyndigheten har undersøkt og de konklusjonene som er trukket på grunnlag av funnene. I revisjonsrapportene blir funnene presentert som avvik eller merknader.

Avvik er mangel på oppfyllelse av krav gitt i eller i medhold av lov eller forskrift. Merknad er forhold som ikke er i strid med krav gitt i eller i medhold av lov eller forskrift, men forhold tilsynsmyndighetene vil påpeke som forbedringsområder i virksomheten.

Det ble gjennomført tilsyn i 27 virksomheter, og funnene fordeler seg som følger:

- 2 virksomheter har fått både avvik og merknader.

- 16 virksomheter har fått avvik, og ingen merknader.

- 7 virksomheter har fått merknader, og ingen avvik.

- 2 virksomheter har fått verken avvik eller merknader.

Videre i dette kapittelet blir det i liten grad referert direkte til avvik og merknader i den enkelte tilsynsrapport, men i stedet er det gitt en sammenfatning av de faktiske forholdene som avvikene og merknadene bygger på. Vi bruker imidlertid sitater fra enkelte tilsynsrapporter for å illustrere, utdype og løfte fram noen funn.

Avvikene som er påpekt ved disse tilsynene, blir fulgt opp av Helsetilsynet i fylkene. De aller fleste avvikene blir vanligvis løst lokalt innen rimelig tid.

\subsection{Forsvarlig pasientbehandling når det er mange pasienter $\mathrm{i}$ akutt- mottaket samtidig}

\subsubsection{Mottak, prioritering og over- våking av pasienter}

Mer enn halvparten av revisjonsrapportene viser at stor pasientpågang kan føre til at akuttmottaket i perioder ikke gjør forsvarlige prioriteringer, og at pasientene ikke blir tilstrekkelig overvåket og fulgt opp mens de venter på legens undersøkelse. Eksempler på funn som underbygger påstanden og blir utdypet videre i dette avsnittet:

- Når det er mange pasienter i akuttmottaket samtidig, og virksomheten ikke har et prioriteringssystem som fungerer, kan det bli tilfeldig hvilke pasienter som kommer først i køen for undersøkelse og diagnostisering. Dermed er det en fare for at pasientene ikke alltid får nødvendige undersøkelser og behandling til riktig tid.

- Ved stor pasientpågang får pasienter med uavklarte diagnoser begrenset 
tilsyn og oppfølging av sykepleierne mens de venter på legeundersøkelse.

- Når det er mange pasienter i mottaket samtidig, har verken sykepleier eller leger oversikt over hvor alvorlig pasientenes tilstand er til enhver tid.

- Personalet har ikke ens praksis og forståelse av hva som er forsvarlig overvåking og oppfølging av pasienter som venter på videre undersøkelse og behandling.

Vanligvis blir pasienter som kommer til akuttmottaket, tatt i mot av en sykepleier som straks må gjøre seg opp en mening om hvor alvorlig pasientens sykdom eller skade er. Sykepleier snakker med og vurderer pasientens tilstand og funksjonsevne, og gjør de første sykepleiefaglige og medisinske observasjoner og vurderinger. Det kan også være aktuelt å sette i gang strakstiltak, som for eksempel å sørge for tilførsel av væske eller gi medikamenter for å lindre smerter. Videre måler sykepleieren blodtrykk, puls, respirasjon, kroppstemperatur og gjør andre observasjoner før legen ser til pasienten. I denne fasen av oppholdet i akuttmottaket blir også det som finnes av dokumentasjon av pasientens tilstand hentet fram og samlet. Parallelt med dette fortsetter sykepleieren å vurdere hvordan det går med pasienten og gjør prioriteringer for å sikre at legen undersøker pasienten innen forsvarlig tid.

For at denne første registreringen og prioriteringen skal være faglig forsvarlig må virksomheten ha et prioriteringssystem; det vil si et sett kriterier som skal danne grunnlag for de første vurderingene av hvor alvorlig sykdomstilstanden er, og hvor raskt videre undersøkelse og diagnostisering av pasienten må skje. Når mange pasienter kommer til mottaket samtidig, kan det være utfordrende å få registrert og prioritert pasientene i riktig rekkefølge.

I de fleste akuttmottakene som er omfattet av dette tilsynet, er det stort sett sykepleierne alene som gjør den første vurderingen av hastegrad og prioriterer pasienten inn i køen som venter på videre undersøkelse og diagnostisering.
Flere av akuttmottakene hadde ikke et prioriteringssystem. Vi fant også at i flere av mottakene som hadde et slikt system, hadde ikke personalet $i$ akuttmottaket samme oppfatning av hvordan prioriteringskriteriene skulle forstås og brukes. Særlig hadde sykepleiere og leger ulik kjennskap til og forståelse av prioriteringssystemet $\mathrm{i}$ virksomhetene. Et par eksempler for å illustrere dette funnet:

"Det er innført et verktøy som sykepleierne benytter til hjelp i prioriteringen av pasientene.

Prioriteringssystemet tar som utgangspunkt at det er sykepleier med scerskilt kompetanse som skal foreta prioriteringen, men i praksis er det de fleste sykepleiere som må foreta denne prioriteringen. Det fremkom ikke at det var etablert et system som sikrer at lege tilser, vurderer og prioriterer nyankomne pasienter."

"Prioriteringskriteria (ABC jf. Norsk medisinsk index) som sjukepleiarane i mottaket bruker, er ikkje konkretiserte og medfører at praksis er forskjellig."

"Akuttmottaket har ikke nedfelt rutiner for prioritering. Det er ulike oppfatninger mellom enkeltpersonell om hvordan prioritering mellom pasienter skjer og hvem som har ansvar for prioriteringen, slik at pasienter blir tilsett av lege innen forsvarlig tid. Dette er spesielt tydelig ved samtidighetskonflikter."

Prioriteringssystemet skal gi retning til og understøtte arbeidsprosessene $\mathrm{i}$ akuttmottaket og er særlig viktig i perioder med stor pågang av pasienter. Det skal hjelpe personalet til ikke å overse alvorlige lidelser, bidra til at de som er alvorligst syke får hjelp først og sikre at det ikke går for lang tid før pasientbehandlingen kommer i gang.

Forsvarlig prioritering henger også nøye sammen med kompetanse. Sykepleieren, og legen om han/hun er involvert tidlig etter ankomst til akuttmottaket, må ha kompetanse til å gjøre medisinskfaglige avveininger og vurderinger som til tider kan være 
komplekse. Funn i dette tilsynet gir grunn til bekymring for om ledelsen i virksomhetene gjør tilstrekkelig for å sikre at personalet som gjør den første prioriteringen, har nødvendig kompetanse til å løse arbeidsoppgavene og dermed sikre forsvarlig pasientbehandling i akuttmottakene. Følgende eksempel kan gi en pekepinn i så måte:

"Det er varierande og ujamn kompetanse hjå sjukepleiar og turnuslegar som møter og vurderer Ø-hjelp pasientane i Akuttmottak"

Dersom sykepleieren er usikker på hvor alvorlig syk pasienten er og hvor mye det haster at pasienten kommer videre $\mathrm{i}$ undersøkelsesprosessen, skal han/hun tilkalle lege som skal bistå i prioriteringsprosessen. Ikke minst kan det være aktuelt $\mathrm{i}$ forhold til den pasientgruppen vi har rettet oppmerksomheten mot i dette tilsynet. Pasienter med uavklarte tilstander kan som tidligere nevnt ha flere samtidig som det kan være vanskelig å tolke, og et sykdomsbilde som ikke peker i en entydig diagnostisk retning. Samtidig kan sykdomstilstanden forverre seg raskt for denne pasientgruppen.

I dette tilsynet har vi flere eksempler på at når det er stor trafikk i akuttmottaket, får ikke alltid pasienter med uavklarte tilstander den medisinske hjelp og pleiefaglige oppfølgingen de trenger raskt nok. Et eksempel som illustrerer dette er følgende:

"Det fremkom i intervjuer at både leger og sykepleiere, ved stor pasientpågang, kan oppleve ikke å ha oversikt over pasientens situasjon og alvorlighetsgrad. Ved gjennomgang av stikkprøver i pasientjournaler fremkom at pasienter med lang liggetid i mottaket hadde begrenset tilsyn/ undersøkelse av sykepleier, også $i$ perioden hvor pasienten ennå ikke hadde blitt tilsett av lege. Dette ble bekreftet $i$ intervjuer. Av stikkprøver $i$ journaler fremkom begrenset dokumentasjon av sykepleiernes observasjon av pasientens tilstand og sykdomsutvikling under oppholdet $i$ akuttmottaket."
Pasientenes tilstand må overvåkes og vurderes kontinuerlig slik at endringer i tilstand som kan påvirke prioriteringen, blir fanget opp med en gang og at strakstiltak blir satt i gang dersom det er nødvendig. Aktuelle strakstiltak kan være å sikre vitale funksjoner, oksygentilførsel, blodtrykksmåling, avhjelpe urinretensjon og å sikre at pasienten ikke faller med mer. Både endring i tilstand og iverksatte strakstiltak skal dokumenteres i pasientens journal.

\subsubsection{Undersøkelse og diagnostikk}

Mer enn halvparten av revisjonsrapportene viser at ved stor pasientpågang er det usikkert om pasientene får faglig forsvarlig undersøkelse og diagnostisering. Følgende er eksempler på funn som blir utdypet videre:

- Når det er mange pasienter i mottaket samtidig, kan det ta lang tid før pasienter blir tilsett av lege. Enkelte rapporter beskriver ventetid opptil 5 timer før pasienten blir vurdert av lege.

- Uerfarne turnusleger må ofte vente lenge på assistentlege for å få bistand til å avklare diagnose.

- Ved stor pågang av pasienter i akuttmottaket kan undersøkelse og diagnostisering bli ufullstendig og mangelfull på grunn av for få egnete undersøkelsesrom.

Etter at pasientene er mottatt, registrert og prioritert blir de undersøkt av lege som skal stille en forløpig diagnose, eventuelt iverksette ytterligere medisinske undersøkelser og behandling. For at undersøkelse og diagnostisering skal være faglig forsvarlig må virksomheten sikre at denne blir gjennomført i rett tid, at nødvendig informasjon er tilgjengelig, at personell med riktig kompetanse gjør relevante kliniske observasjoner og undersøkelser, samt vurderer om det er nødvendig å supplere med laboratorieog røntgenundersøkelser. De fysiske forholdene i akuttmottaket har også betydning i denne sammenhengen. 
Legeundersøkelse til rett tid?

Hvor fort legeundersøkelsen kan gjøres, avhenger i de fleste akuttmottakene av hvor mange pasienter som er i akuttmottaket samtidig, tid på døgnet og hvor mange leger som er tilgjengelige til enhver tid. Ved knapphet på ressurser vil det være sykepleierens prioritering og pasientens symptomer og sykdomstegn som avgjør hvem legen går til først. I situasjoner der legene er opptatt med andre pasienter, vil sykepleiernes vurderinger være bestemmende for det videre forløpet for pasienten. Systemer for hvordan og når lege skal tilkalles er helt avgjørende for forsvarlig undersøkelse og diagnostisering, og dermed også for forsvarlig medisinsk behandling.

I dette tilsynet er det flere eksempler på at pasienter med uavklarte diagnoser må vente opp til fem timer på at legen skal komme når det er som travlest $\mathrm{i}$ akuttmottaket. Følgende sitater fra en revisjonsrapport illustrerer dette:

"Det fremkom at uavklarte pasienter kan bli liggende i mottaket over tid før de blir tilsett og vurdert av lege. Gjennomgang av stikkprøver på journaler viste at det tok fra 0 til 5 timer fra registrert ankomst til mottaket, til det var dokumentert at pasientene ble undersøkt av lege."

"Gjennomgang av stikkprøver på journaler for 20 pasienter $i$ aldergruppen $80+$ viste at det tok opp til 5 timer fra pasientene var registrert som ankommet til mottaket til lege tok opp innkomstjournal. Det forela ikke dokumentasjon for at pasientene var tilsett og vurdert av lege før dette."

"Intervjuer viser at hver enkelt sykepleier og lege har ansvar for et for stort antall pasienter når pasientpågangen er stor. Mange av de intervjuede uttrykte bekymring for å overse alvorlige tilstander hos pasientene."

Isolert sett representerer ikke ventetiden en absolutt grense for hva som er forsvarlig pasientbehandling. Det vesentligste er at pasientene blir observert og fulgt opp mens de venter, at personellet har relevant kompetanse og setter i gang hensiktsmessige tiltak i tide.

\section{Lege med rett kompetanse?}

I de fleste akuttmottakene i dette tilsynet var det turnusleger som gjorde de første legeundersøkelsene. Det varierte mellom virksomhetene hvor godt opplærings- og introduksjonsprogram de har for personalet i akuttmottaket; særlig mangler det systematiske opplegg for å forberede turnusleger og andre nye leger på rutinene, arbeidsprosessene og arbeidsoppgavene $\mathrm{i}$ akuttmottaket. Videre varierte det hvor gode ordninger som var etablert for å understøtte og bistå uerfarne leger i deres faglige arbeid. Følgende eksempler fra revisjonsrapporter kan illustrere dette:

"Sykepleiere og turnusleger som vurderer pasienter som kommer for øyeblikkelig hjelp, har varierende kompetanse."

"Det fremkom av intervjuer at turnusleger fär begrenset opplaering og oppfølging $i$ startfasen $i$ sin tjeneste $i$ akuttmottaket $i$ forhold til praktiske rutiner og nye komplekse situasjoner som møter dem."

"Av intervjuer, bemanningsplaner og dokumentasjon fremkom behov for økt legekompetanse i Akuttmottaket. Det vises til at ivaretakelsen av pasientene, hva gjelder prioritering, utredning og diagnostikk, $i$ hovedsak baseres på sykepleiere og turnusleger. Ass.legene er informert om og tillagt det medisinskfaglige ansvaret for pasientene i Akuttmottaket. De er bakvakt for turnuslegene. Ved stor pasientpågang fremkom at ass.legen regelmessig kan vore vanskelig å få tak i for turnuslegene."

"Det fremkom i intervju at når en turnuslege er faglig usikker, kan det ta flere timer før ass.lege $i$ Kirugisk klinikk blir tilgjengelig og kan bidra til diagnostisk avklaring."

Når uerfarne leger med varierende kompetanse og erfaring er første lege som møter pasienten, må virksomheten 
sikre fleksible og robuste ordninger med lav terskel for å tilkalle mer erfarne leger med mer spesialisert kompetanse.

På vei til og fra røntgenundersøkelse Dersom pasienten skal til røntgenundersøkelser, skjer det som oftest et annet sted i sykehuset enn der akuttmottaket ligger, noe som fordrer transport av pasienten. I denne perioden må akuttmottaket ha oversikt over hva som skjer med pasienten og hvor vedkommende befinner seg.

Hvem som transporterer pasientene til røntgen, kan variere mellom sykepleiere fra akuttmottaket, portører eller personell fra andre sykehusavdelinger.

Dersom sykehuset benytter annet personell til transport enn pleiepersonell fra mottaket, er det særlig viktig at virksomheten forsikrer seg om at pasienten får forsvarlig overvåking, pleie og eventuelt smertelindring - også i den perioden som pasienten ikke befinner seg i mottaket. Fordi det fortsatt er akuttmottaket som har ansvaret for forsvarlig pasientbehandling, må virksomheten ha rutiner og praksis som sikrer kommunikasjon mellom dette personellet og mottaket.

Eksemplene nedenfor viser at dette ikke er like klart i alle akuttmottakene:

"Når pasienter skal fra akuttmottaket via røntgen til post, er det uklart hvem som har ansvar for observasjon og behandling av pasienten røntgen, akuttmottaket eller posten."

"Av intervjuer fremkom at det ikke er avklart hvem som har pleieansvaret for pasienter i perioden fra portør transporterer dem fra akuttmottaket, for eksempel via røntgen, og til de ankommer sengeposten."

\section{Når det er trangt om plassen i akutt- mottaket}

Som allerede vist, befinner det seg ofte mange pasienter i akuttmottaket på en gang, og ikke rent sjelden flere enn akuttmottaket har kapasitet til å ta i mot. Det vil si at i perioder kan det mangle nok egnete rom til å gjøre nødvendige undersøkelser og å gi nødvendig behandling og pleie. Dette medfører at pasientbehandlingen ikke er faglig forsvarlig til enhver tid i nærmere halvparten av akuttmottakene i dette tilsynet. Følgende eksempler kan illustrere dette poenget:
"Ved befaring og av intervjuer fremkom det at ved stor pasient- pågang, må pasienter undersøkes bl.a. $i$ ventehall, korridor, observa- sjonsposten, m.v. hvor andre pasien- ter/pårørende oppholder seg. Av intervjuene fremkom bekymring for redusert mulighet til oversikt og adekvat overvåkning under slike forhold."

"Pasienter venter på ledige undersøkelsesrom. Begrenset antall undersøkelsesrom og begrenset tilgang på lege kan forsinke diagnostikk og oppstart av behandling. Med mange pasienter $i$ ventehallen kan det vare vanskelig å ivareta taushetsplikt og integritet."

Når undersøkelse og diagnostisering må foregå i korridorer og bak forheng på flersengsrom, kan den bli ufullstendig og mangelfull. For både sykepleiere og leger oppstår det en konflikt mellom å bryte taushetsplikten og å gjøre nødvendige undersøkelser. De kan kvie seg for å stille spørsmål som kan oppfattes som sensitive og nærgående, og pasienten kan kvie seg for å svare. Konsekvensen kan være forsinket og/eller mangelfull pasientbehandling.

\subsubsection{Observasjon og medisinsk opp- følging av pasienter $i$ ventetid før overføring til post}

Snaut halvparten av revisjonsrapportene viser at ved stor pasientpågang $i$ akuttmottaket er det usikkert om pasienter får forsvarlig medisinsk oppfølging, tilsyn, pleie og omsorg mens de venter på overføring til post. Eksempler på funn:

- Ved plassmangel i de øvrige avdelingene i sykehuset kan overføring fra akuttmottaket være en flaskehals som gir pasienten lang ventetid i mottaket.

- Mottakets lokaler er lite egnet til å ha pasienter liggende over lang tid, både 
i forhold til tilstrekkelig plass, tilstrekkelig tilsyn og i forhold til matservering, medikamenter og ivaretakelse av pårørende.

- Når det er mange pasienter i akuttmottaket samtidig, er det fare for at pasientene ikke blir observert og fulgt opp godt nok og dermed at vesentlige endringer i pasientens sykdomsutvikling blir oversett.

Når alle undersøkelser er utført og alle papirer klargjort fra akuttmottaket, skal pasienten i utgangspunktet flyttes til den sykehusavdelingen som skal videreføre eller starte opp med annen medisinsk behandling. Hvor fort pasienten flyttes fra akuttmottaket, er avhengig av disponible sengeplasser på sengepostene.

I dette tilsynet fant vi flere eksempler på at pasienter må vente lenge i mottaket før de ble overført til en av de andre avdelingene i sykehuset. Vi fant også at kunne det være svært begrenset hvor mye tilsyn og oppfølging pasientene fikk i denne ventetiden, særlig når trafikken i mottaket var stor:

"Muligheten for god observasjon av pasienter i Mottagelsesavdelingen reduseres når belegget er stort. Nyankomne pasienter tar oppmerksomhet fra pasienter som er avklart og klare for à komme på post. Dette kan fore til at ferdigavklarte pasienter ikke får god nok oppfølging i form av jevnlig observasjon og tilsyn av sykepleier, at de fär sine medikamenter, at de fär nødvendig mat og drikke, mens de venter i Mottagelsesavdelingen. Risikoen for at nye situasjoner kan oppstå hos disse uten å bli oppdaget, øker. Det foreligger flere skriftlige bekymringsmeldinger om plasseringsproblemene."

"Ved opphopning av pasienter må ofte pasienter flyttes til andre steder $i$ akuttmottaket. Dette medfører skifte av pasientansvarlig sykepleier (PAS) og fare for manglende kontinuitet $i$ oppfølging og behandling."

"For å unngå at pasienter undersøkes på korridor eller flersengsrom skjer det en stadig flytting av pasienter fra rom til rom/korridor med merking av senger når oppsatte plasser er belagt. Det er risiko for at ansatte mister oversikt over pasientene og det har skjedd forbytting av pasientopplysninger/identitet."

Flere av akuttmottakene i dette tilsynet hadde heller ikke etablert ens rutiner og praksis for å overvåke og dokumentere pasientens tilstand i ventetiden.

Plassmangel i de øvrige sykehusavdelingene kan med andre ord bety en flaskehals ved at pasienter som er ferdig undersøkt i mottaket ikke kan overflyttes, men blir liggende i akuttmottaket å vente. Samtidig er det ofte slik at akuttmottakets lokaler er lite egnet til å ha pasienter liggende over lang tid, både fordi det er begrenset plass til rådighet, fordi mulighetene for å tilstrekkelig tilsyn er begrenset, og fordi de fleste akuttmottakene har begrensede muligheter for å servere mat og å ivareta pårørende. I tillegg kan noen pasienter også ha behov for at medisinske strakstiltak blir satt i gang dersom sykdomstilstanden endrer seg i ventetiden. For personalet $i$ akuttmottaket betyr dette ekstra ansvar og arbeidsoppgaver som normalt ville blitt ivaretatt av personellet på sengeposten.

For pasienten kan ventetiden også innebære at planlagt behandling og oppfølging ikke blir satt i gang. Samlet sett kan dette bety en risiko for at pasienter ikke får forsvarlig medisinsk oppfølging og behandling, nødvendig tilsyn, pleie og omsorg mens de venter på å bli overført til den aktuelle sengeavdelingen.

\subsection{Ledelse, organisering og sty- ring som forutsetning for forsvarlig pasientbehandling i akuttmottaket}

I dette tilsynet har vi rettet oppmerksomheten mot sammenhengen mellom faglige og styringsmessige utfordringer knyttet til oppgaveløsningen i akuttmottaket, og i forrige kapittel viste vi at i perioder med stor pågang og opphopning av pasienter er ikke pasientbehandlingen i akuttmottaket forsvarlig til 
enhver tid. I dette kapittelet presenterer vi funn som viser om og hvordan virksomhetens ledelse ivaretar ansvaret for forsvarlig pasientbehandling.

\subsubsection{Koordinering og styring for å sikre forsvarlig pasientbehandling}

I alt 24 av 27 rapporter viser at mangelfull koordinering og styring av aktivitetene og ressursene i akuttmottaket kan gi mangelfull pasientbehandling.

Følgende er eksempler på på funn som blir utdypet videre:

- Aktivitetstall fra akuttmottaket blir ikke oppsummert, sammenstilt og brukt av ledelsen til systematisk gjennomgang av driften og til å gjøre risikovurderinger, og dermed sikre forsvarlig planlegging og styring av medisinskfaglig og sykepleiefaglig bemanning i akuttmottaket.

- I mange av akuttmottakene i dette tilsynet hadde ikke ledelsen oversikt over belastningen i mottaket til ulike tider gjennom døgnet, uka eller året.

- Systematiske oversikter over pasientstrømmen blir ikke brukt til å evaluere om medisinsk diagnose og undersøkelse blir gjennomført innen forsvarlig tid og til å identifisere kritiske trinn i pasientforløpet.

- Flere av virksomhetene mangler systematisk oversikt over og vurderinger av hvilke konsekvenser opphopning av pasienter i akuttmottaket kan ha for forsvarlig pasientbehandling.

- Rutiner og prosedyrer for aktiviteter og prosesser er lite kjent og benyttet av personalet i mottaket, som for eksempel hvor lenge pasienter kan vente før de undersøkes av lege, hvem som tilkaller ekstra ressurser ved aktivitetstopper.

- Helseforetakenes kvalitetsstyringssystemer er mangelfulle eller ikke tilstrekkelig tatt i bruk, særlig den delen som dreier seg om å evaluere og korrigere virksomheten systematisk, herunder å bruke avviksbehandlingssystemene i ledelsens planmessige og strategiske forbedringsarbeid i virk- somheten.

- Å lære av uønskede hendelser og svikt i akuttmottakene er preget av å være ad hoc-øvelser mer enn som et ledd i strategisk forbedrings- og utviklingsarbeid.

Pasienter i akuttmottaket skal som tidligere beskrevet, bli prioritert og vurdert av sykepleier, undersøkt og diagnostisert av lege, overvåket og behandlet på en planlagt, organisert og forutsigbar måte. Ledere på ulike nivåer og i de ulike avdelingene som er involvert $i$ driften av akuttmottaket, skal følge opp at dette skjer.

Følgende eksempler illustrerer at i de fleste helseforetakene i dette tilsynet arbeider ikke ledelsen tilstrekkelig systematisk og målrettet for å sikre forsvarlig drift og pasientbehandling $\mathrm{i}$ akuttmottakene:

"Det er ikke entydig og kjent hvem $i$ helseforetaket som har overordnet ansvar for alle aktiviteter og ressurser tilknyttet virksomheten i akuttmottaket. Det er revitalisert et samarbeidsforum (uten besluttende myndighet) for å bedre samhandlingen mellom de ulike involverte klinikker. Forumet er ikke gitt formelt mandat og baseres på konsensus. Ved uenighet foreligger ikke retningslinjer for hvordan forhold skal avklares."

" Driftsresultater i akuttmottaket blir i liten grad systematisk gjennomgått for à sikre faglig forsvarlig pasientbehandling. Dette gjelder for alle klinikker som er ansvarlig for deler av driften i akuttmottaket. Utfordringene $i$ akuttmottaket er gjennom tidligere internrevisjon kjent for helseforetakets ledelse. Det er imidlertid ikke sikret at alle påpekte forhold er blitt rettet opp. De involverte klinikkledelsene er kjent med utfordringene $i$ akuttmottaket gjennom internrevisjoner, avviksmeldinger, pasientoversikter m.m. Dette er tatt opp i ledermøte og andre aktuelle fora. Det er gjort enkelte tiltak for à bedre pasientflyten. Intervju og verifikasjon viser at man ikke har rutiner for systematisk evaluering av om igangsatte tiltak 
har hatt ønsket effekt. Akuttmottaket bruker i liten grad tilgjengelige data for systematisk a identifisere risikoforhold $i$ avdelingen."

"Trass $i$ stor auke i pasienttilstrøyminga er det ikkje gjort systematiske risikovurderingar av aktivitetane $i$ Akuttmottaket. I løpet av dei siste to åra er det til dømes ikkje gjort ei samla vurdering av om meir erfarne legar burde ta i mot, vurdere og starte behandling av pasientar $i$ Akuttmottak. Det ligg føre skriftlege prosedyrer på dei fleste omràda. Desse er oppdaterte og tilgjengelege, men dei blir ikkje alltid følgde."

"Tall på oppholdstid i Akuttmottaket, ventetid på legeundersøkelse, avviksmeldinger om ventetid på legeundersøkelse og andre meldte avvik, ble ikke brukt $i$ en systematisk sammenheng for å overvåke aktiviteten $i$ Akuttmottaket."

Dette er hovedfunn som vi kommer med utdypende kommentarer til i kapittel 4 Statens helsetilsyns vurdering.

\subsubsection{Rutiner og praksis for kommuni- kasjon og samhandling mellom helse- personell}

Flere av virksomhetene i dette tilsynet mangler innarbeidete rutiner og praksis som sikrer at personalet $\mathrm{i}$ akuttmottaket har felles oppfatning av hvordan sentrale arbeidsprosesser og arbeidsoppgaver skal forløpe for at pasientbehandlingen skal være forsvarlig. Følgende er eksempler på funn:

- Mange av virksomhetene har mangelfulle rutiner for samhandling og kommunikasjon mellom sykepleiere og leger som har oppgaver i akuttmottaket.

- Retningslinjer, rutiner og prosedyrer for aktiviteter og prosesser i akuttmottaket har vært lite kjent og benyttet av personalet i mottaket.

- Personalet som har oppgaver i akuttmottaket, har ikke ens forståelse av hva som er akseptabel ventetid før medisinsk undersøkelse og behand- ling kommer i gang.

Dette er funn som for eksempel dreier seg om at leger og sykepleiere ikke har ens oppfatning av hvor lenge pasienter skal vente før de undersøkes av lege, eller av hvordan pasienter som blir liggende og vente, skal overvåkes og følges opp. Akuttmottaket må også ha rutiner og praksis for å sikre at beskjeder om det som skjer med pasienten, blir gitt mellom helsepersonellet og at opplysninger om pasientens tilstand blir notert og dokumentert. Også på dette området har tilsynet avdekket svikt i flere av virksomhetene.

Det er også uklart i flere av akuttmottakene hvem som skal tilkalle, følge opp og koordinere personell som organisatorisk ikke hører til i akuttmottaket, og hva som er kriteriene for å tilkalle mer personell eller personell med høyere kompetanse fra avdelinger som er involvert i pasientbehandlingen i akuttmottaket.

Følgende eksempel illustrerer dette poenget:

"Intervjuene viser at det er uklart hvem som tilkaller ekstra personell $i$ akuttmottaket. Akuttmottaket har skriftlig prosedyre på området, men intervjuene viser at prosedyren blir forstått og anvendt ulikt av leger og sykepleiere. Intervjuene viser også at det er ingen omforent forståelse hos leger og sykepleiere om hvordan overbelastninger skal håndteres."

Et akuttmottak er preget av hektisk aktivitet og mye personell som er innom med ujevne mellomrom. Det er derfor viktig at alle har klar og felles forståelse av den enkeltes arbeidsoppgaver, ansvar og myndighet. Dette gjelder også akuttmottakets faste personell. Alle som yter helsetjenester i akuttmottaket skal ha klare fullmakter der ansvar og myndighet er tydeliggjort.

Helseforetaket skal ha etablert resultatmål/ aktivitetsmål for akuttmottakets virksomhet. Det skal være kjente mål som gjenspeiles i prioriteringskriterier og andre rutiner som styrer pasientstrømmen og pasientbehandlingen. 


\subsubsection{Kompetansebygging og kompe- tansestyring}

Halvparten av revisjonsrapportene påpeker mangelfull kompetanse $\mathrm{og}$ lite robuste ordninger for å tilkalle mer erfarne leger med høyere kompetanse til akuttmottakene. Følgende er eksempler på funn som blir utdypet nedenfor:

- Flere helseforetak mangler rutiner og praksis for systematisk opplæring og oppfølging av turnusleger eller assistentleger som er nye i akuttmottaket, både $\mathrm{i}$ forhold til administrative og medisinske prosedyrer.

- Selv i helseforetak som har opplæringsplaner for leger og sykepleiere som skal arbeide i akuttmottaket, blir de ikke alltid fulgt.

- Flere akuttmottak mangler rutiner og praksis for når leger med mer erfaring skal tilkalles fra andre avdelinger i sykehuset for å bistå leger er på vakt i akuttmottaket.

Virksomheten må planlegge med tilstrekkelig bemanning i forhold til forventet aktivitet ved normal belastning, men må også ha konkrete retningslinjer for hvordan situasjoner med unormalt stor belastning, eller "hverdagskriser", skal håndteres. For å sikre en forsvarlig drift må ledelsen være kjent med variasjoner $i$ arbeidsbelastningen og følge opp med realistiske planer for hvordan de vil disponere ressursene; med andre ord: hvordan de vil sikre at det er nok personell med nødvendig kompetanse i akuttmottaket til enhver tid. Det skal være definert kompetansebehov for de ulike funksjonene personellet skal fylle i akuttmottaket, og personellet skal ha fått nødvendig innsikt i akuttmottakets rutiner og praksis før de kan yte helsetjenester der på egen hånd.

De fleste akuttmottakene i dette tilsynet sikrer ikke godt nok at de har nødvendig bemanning og kompetanse tilgjengelig for å kunne gi forsvarlig pasientbehandling i perioder med stor trafikk i akuttmottaket. Noen eksempler for å illustrere dette:

\section{"Ved intervjuer fremkommer det at} kompetansen $i$ akuttmottaket er et risikoområde. Det er blant annet en fare for at feil eller mangelfulle medisinske vurderinger kan føre til feil eller forsinket behandling eller videre undersøkelser. De helt uerfarne turnuslegene er primcervakt, dette blir på alle nivå $i$ organisasjonen vurdert til å vare en stor utfordring. Det er likevel ikke iverksatt systematiske vurderinger eller tiltak i forhold til dette. Det er ulik praksis blant legene når de kontakter/tilkaller bakvakt ved behov for ytterligere kompetanse. Legene i overordnede stillinger hevdet det var lav terskel for å tilkalle hjelp og la vekt på at dette var noe som ble tydelig formidlet. Intervjuer av sykepleiere og underordnede leger gav imidlertid inntrykk av at det var en høy terskel for å tilkalle hjelp. Det var heller ingen kultur for at sykepleierne tilkalte mer kompetent medisinsk hjelp."

\section{"Opplcering av nyansatte leger og sykepleiere følger ikke en oppsatt plan. Vedlikehold av kompetanse er ikke styrt etter de behov som finnes. Det er ingen plan for løpende inter- nundervisning. Selvmelding fra syke- pleiere om deres kompetanse benyttes ikke til oppfolging av den enkelte ansatte, og benyttes ikke som et ledd $i$ den samlede kompetanseutvikling for avdelingen."}

Bemanningen i akuttmottaket skal være tilpasset oppgavene som varierer både gjennom døgnet og i forhold til helger, ferier og høytider. Knapphet på ressurser og tidsfaktoren vil alltid være risikofaktorer i akuttmottakene. Derfor må tilgjengelige personellressurser styres slik at de dårligste pasientene alltid kan prioriteres.

\subsubsection{Om å lære av svikt og uønskede hendelser for å sikre forsvarlig pasi- entbehandling}

Mer enn halvparten av revisjonsrapportene viser at foretakene har mangelfulle systemer for å melde, følge opp og rette opp svikt og uønskede hendelser knyttet til pasientbehandling i akuttmottaket. Eksempler på funn som underbygger påstanden, og blir utdypet videre i dette avsnittet: 
- Selv om mange av akuttmottakene har et system for avviksbehandling meldes ikke avvik som dreier seg om svikt i daglige rutiner, samtidighetskonflikter og hverdagskriser.

- Foretakene bruker ikke system for avviksbehandling til å ha oversikt over og følge opp risikoområder i akuttmottakene.

Helseforetaket skal ha et fungerende avviksbehandlingssystem som fanger opp, retter opp og forebygger risiko for svikt i pasientbehandlingen i akuttmottaket. Et slikt system kan bestå av avviksskjemaer, forbedringsskjemaer, rapporteringsbøker, evalueringer, møter med mer. Formålet med systemet er at virksomheten på en systematisk måte skal samle kunnskap om svikt i egen virksomhet og bruke det slik at akuttmottaket og helseforetaket kan lære av egne, og gjerne også andres, feil. Det vil med andre ord si at kunnskap om svikt skal benyttes i arbeidet med forbedring og utvikling av pasientbehandlingen.

Funn fra dette tilsynet tyder på at helseforetakene og spesielt akuttmottakene er kommet kort når det gjelder etablering av velfungerende avviksbehandlingssystem. Også i de virksomhetene som har nedfelt rutiner for å melde avvik, gjenstår mye arbeid fra ledelsens side for å få på plass lik praksis blant de ansatte for å melde avvik knyttet til virksomhetens resultatmål, for eksempel når det oppstår situasjoner med for mange pasienter i akuttmottaket samtidig sett $\mathrm{i}$ forhold til de tilgjengelige driftsressurser på det aktuelle tidspunktet. I flere av virksomhetene gjenstår det også mye før det kan sies at ledelsen bruker avviksmeldingene på en systematisk måte i sin gjennomgang av virksomheten.

Følgende eksempler illustrerer dette poenget:

"Det er etablert avviksbehandlingssystemer $i$ helseforetaket. Det meldes i liten grad avvik på svikt knyttet til vedtatte mål, prioriteringer, tiltak og aktiviteter som for eksempel ved samtidighetskonflikter.'
"Foretaket har ikke tatt avvikssystemet systematisk i bruk for å holde seg orientert om og følge opp erkjente risikoområder i mottaket."

"Intervjuer viste at virksomhetens avvikssystem var begrenset kjent, og $i$ varierende grad tatt i bruk av ansatte som hadde sin aktivitet i mottaket."

"Avvik diskuteres ikke på tvers av profesjoner, avdelinger og klinikker slik at rutiner kan endres på en hensiktsmessig måte."

Det er altså ikke bare alvorlige pasientskader som skal meldes eller tas opp, men svikt i daglige rutiner og svikt i forhold til mål som er fastsatt for virksomheten. Svikt i akuttmottaket involverer gjerne personell fra flere avdelinger i sykehuset. For at virksomheten skal kunne iverksette effektive og relevante tiltak for å rette opp uheldige forhold, er det helt vesentlig at avviksbehandlingen omfatter alt personell og alle avdelinger som er involverte. 


\section{Statens helsetilsyns vurdering}

Vi har presentert funn som Helsetilsynet i fylkene har gjort i 27 av landets 54 akuttmottak.

Statens helsetilsyn har funnet et totalbilde som gir grunnlag for å konkludere med at hverdagen i akuttmottakene er preget av mangelfull styring og ledelse. Dette gir til tider uforsvarlig pasientbehandling. I de fleste av akuttmottakene som er omfattet av tilsynet, henger for mye av den daglige driften på at kompetente enkeltpersoner i akuttmottaket "bretter opp ermene" og strekker seg svært langt for å løse kinkige situasjoner, hverdagskriser og flaskehalsproblematikk. For helsepersonellet i akuttmottaket betyr dette unødvendig stor belastning og slitasje som i sin tur kan få uønskede konsekvenser for behandlingen av pasientene. Særlig blir dette tydelig i perioder når det hoper seg opp med pasienter som enten venter på lege, eller når pasienter venter på å bli overført til en annen avdeling i sykehuset. At det befinner seg mange pasienter i akuttmottaket samtidig er et hverdagsfenomen, ikke en unntakstilstand. Det synes å være et mønster at ad hoc-løsninger og kriseadministrasjon snarere enn systematisk styring redder pressede situasjoner fra å utvikle seg til uønskede hendelser og svikt. Samlet sett giør dette at faren for svikt er så stor at kravet til forsvarlig drift ikke kan anses å være oppfylt. Statens helsetilsyn finner dette uakseptabelt. I dette kapittelet utdyper vi denne konklusjonen.

\subsection{Organisering, koordinering og styring for å sikre forsvarlig pasi- entbehandling}

Krav til å yte forsvarlige tjenester etter spesialisthelsetjenesteloven $\S 2-2$, sammen med forskrift om internkontroll $i$ sosial- og helsetjenesten, stiller krav til ledelse, organisering og styring. Det er ledelsen i helseforetaket som har ansvar for å sikre at daglige arbeidsoppgaver blir planlagt, organisert, utført og forbedret i samsvar med krav i helselovgivningen.

Som beskrevet foran, er vanligvis flere avdelinger i sykehuset involvert i tjenesteytingen i akuttmottaket. I mange av akuttmottakene er administrerende direktør første felles organisatoriske nivå i helseforetaket, noe som betyr at det er dette ledelsesnivået som har ansvar for styring, koordinering og oppfølging av arbeidet i akuttmottaket. Daglig leder i akuttmottaket skal ivareta daglig styring og koordinering i tråd med retningslinjer og delegasjoner. Det skal være implementert et kvalitetsstyringssystem som tilfredsstiller kravene i internkontrollforskriften, og som sikrer forsvarlig virksomhet i akuttmottaket.

Ressurs- og kompetansestyringen i akuttmottakene kan synes å være underlagt et "mangehodet" lederskap, illustrert blant annet ved at legene som arbeider der styres fra andre avdelinger. Etter vår vurdering er det grunn til å understreke at en slik organisering forsterker behovet for tydelige styrings- og rapporteringslinjer, og fordrer kontinu- 
erlig oppmerksomhet og systematisk oppfølging fra helseforetakets ledelse. I mange virksomheter i dette tilsynet var helseforetakenes styringssystemer mangelfulle og tilfredsstiller ikke helselovgivningens krav. Særlig var den delen av kvalitetsstyringen som dreier seg om å evaluere og korrigere virksomheten på en systematisk måte dårlig utviklet, og ikke tilstrekkelig tatt i bruk. For eksempel er det et gjennomgående funn er at helseforetakene ikke har etablert resultatmål/aktivitetsmål for akuttmottakenes virksomhet, og at nødvendige styringsdata ofte ikke blir registrert eller brukt. Aktivitetsdata fra akuttmottaket blir ikke brukt til å overvåke driften og å gjøre risikovurderinger, noe som er nødvendig for å sikre forsvarlig planlegging og styring av medisinskfaglig og sykepleiefaglig bemanning $i$ akuttmottaket.

Statens helsetilsyn mener det er uakseptabelt at 24 av 27 tilsyn viser mangelfull koordinering og styring av aktivitetene og ressursene i akuttmottaket, og derved gir mangelfull pasientbehandling. Ledelsen i disse helseforetakene ser ikke ut til å etterspørre på en systematisk måte hva som skjer i akuttmottakene.

Ledelsen brukte heller ikke systematiske oversikter over pasientstrømmen for å evaluere om undersøkelse blir gjennomført innen forsvarlig tid og til å identifisere andre kritiske trinn i behandlingsforløpet. Flere av virksomhetene manglet oversikt over og vurderinger av hvilke konsekvenser det kan ha for forsvarlig pasientbehandling at det i perioder oppstår flaskehalser og hoper seg opp med pasienter i akuttmottaket.

Flere av akuttmottakene hadde ikke et velfungerende avviksbehandlingssystem. Det dreier seg både om at de ikke har på plass rutiner og ens praksis blant de ansatte for å melde avvik knyttet til virksomhetens aktivitets- og resultatmål, og om at ledelsen ikke bruker avviksmeldingene på en systematisk måte i sin gjennomgang av virksomheten.

Hensikten med et avviksbehandlingssystem er at virksomheten skal bruke kunnskap om svikt i egen virksomhet til forbedring og utvikling av pasientbehandlingen. Det er ikke bare de alvorlige pasientskadene som skal meldes eller tas opp, men svikt i daglige rutiner. Svikt i akuttmottaket involverer gjerne personell fra flere avdelinger $i$ sykehuset. Alle som yter helsetjenester i akuttmottaket skal være kjent med akuttmottakets rutiner, og melde fra om avvik som skjer under tjenesteyting i akuttmottaket. Det er derfor helt vesentlig at avviksbehandlingen inkluderer alt personell fra alle involverte avdelinger.

For å sikre forsvarlig tjenesteyting skal avviksbehandling være en prioritert oppgave som ledelsen skal jobbe med systematisk og kontinuerlig. Ledelsen skal følge opp at avvikene blir rettet opp, at korrigerende tiltak virker som forutsatt, at prosedyrer endres om nødvendig og at avvik som ikke lukkes innen akseptabel tid løftes opp i organisasjonen.

Statens helsetilsyn ser alvorlig på at ledelsen i helseforetakene ikke arbeider tilstrekkelig systematisk med å lære av svikt $i$ egen virksomhet og å bruke kunnskap om svikt til forbedringsarbeid og sikring av forsvarlig pasientbehandling.

Samlet sett betyr dette at ledelsen har dårlig oversikt over driften i akuttmottakene, og heller ikke gjør seg opp en mening om hva som kan være kritiske trinn $i$ arbeidsprosessene og oppgaveløsningen; for så å kunne sette i gang målrettede tiltak for å rette opp forholdene slik at faren for svikt blir mindre og pasientsikkerheten blir bedre. Med andre ord gjør ikke ledelsen i de fleste helseforetakene nok for å sikre forsvarlig pasientbehandling i akuttmottakene slik helselovgivningen pålegger.

Statens helsetilsyn ser det som en alvorlig svikt i helseforetakenes styringssystem at de fleste akuttmottakene ikke sikrer godt nok tilgang til den bemanning og kompetanse som er nødvendig for å gi forsvarlig pasientbehandling, også i perioder med stor trafikk. Dette blir ytterligere forsterket når mange pasienter $i$ akuttmottaket samtidig er et hverdagsfenomen, og når overføring til 
andre avdelinger i sykehuset viser seg å være en flaskehals $i$ akuttmottakene $i$ dette tilsynet.

\subsection{Forsvarlig prioritering, over- våkning og undersøkelse av pasienter}

Funnene i dette tilsynet viser også en bekymringsfull svikt knyttet til sentrale arbeidsoppgaver og arbeidsprosesser i mange akuttmottak. Det gjelder forhold knyttet til prioritering og overvåkning av pasienter, samt nødvendig kommunikasjon om pasientens tilstand. Dels mangler nødvendige systemer, dels er rutiner og prosedyrer lite kjent og fulgt av personalet i akuttmottaket. I tillegg er manglende plass i akuttmottaket i perioder en stor risiko for svikt i pasientbehandlingen.

\section{Forsvarlig prioritering av pasienter}

Flere av akuttmottakene hadde ikke etablert tiltak og retningslinjer for å sikre forsvarlig mottak og prioritering av pasientene når de kommer til akuttmottaket. Vi fant også at i flere av akuttmottakene som hadde vedtatte retningslinjer for hvordan mottak og prioritering skulle foregå, var ikke leger og sykepleiere omforente om hvordan prioriteringssystemet skulle praktiseres. Virksomheten må ha rutiner og ens praksis for å sikre at alle pasientene som kommer inn døra til akuttmottaket blir fanget opp, registrert og vurdert i prioriteringskøen slik at de som trenger medisinsk hjelp raskest, făr det. I tillegg til å samle mest mulig informasjon om pasienten, skal klokkeslettet for når pasienten kommer til akuttmottaket registreres. Det gir virksomheten mulighet til å ha oversikt over hvor lenge den enkelte pasient venter på legens undersøkelse og diagnostisering, og dermed ha grunnlag for å kunne vurdere hva som er forsvarlig ventetid. Videre gir det ledelsen mulighet for å følge med på hvor lang tid det går før pasienter blir overført til en annen avdeling i sykehuset for videre medisinsk behandling når akuttmottaket er ferdig med undersøkelse og diagnostisering.

Fastlagte retningslinjer eller kriterier for mottak og prioritering er ett av flere elementer i virksomhetens styringssystem for å sikre forsvarlig pasientbehandling og dermed øke pasientsikkerheten i akuttmottaket. For at retningslinjene skal fungere formålstjenelig må de være kjent og fulgt av alle som arbeider i akuttmottaket, og være kjent av de andre avdelingene $\mathrm{i}$ sykehuset som er involvert akuttmottakets daglige drift.

\section{Forsvarlig overvåking av og kommu-} nikasjon om pasienter $i$ akuttmottaket I de aller fleste akuttmottakene er det vanlig at det i perioder er mange pasienter der samtidig. Ved stor pågang kan pasienter med uavklarte diagnoser bli nedprioritert i forhold til akutt syke pasienter med klare diagnoser. Dersom det kommer nye pasienter til mottaket når det allerede er mange der fra før, er det utfordrende for personalet å ha god nok oversikt over alle pasientene til enhver tid.

I dette tilsynet fant vi at ved stor trafikk i akuttmottaket må pasienter med uavklarte tilstander vente flere timer på legens undersøkelse og diagnostisering, og at i slike situasjoner blir ikke pasientene tilstrekkelig overvåket og fulgt opp av sykepleierne. Videre fant vi også her at personalet ikke har ens praksis og forståelse av hva som er tilstrekkelig overvåking og oppfølging av pasienter som venter på videre undersøkelse og behandling.

Lang ventetid kan øke faren for at pasientens sykdomstilstand blir forverret, at pasienten blir forvirret, får for lite væsketilførsel og ikke får nødvendig smertelindring. Ikke minst gjelder dette for eldre pasienter som blir sykere raskere ved kjemisk og fysiologisk ubalanse i kroppen. For å unngå at så skjer må virksomheten sikre at noen har ansvar for fortløpende observasjon og oppfølging også av disse pasientene. Det skal være klart hvem som overvåker den enkelte pasient og hvem som har det medisinske ansvaret for de ulike pasientene. Akuttmottaket skal til enhver tid ha oversikt over alle pasienter som oppholder seg i akuttmottaket, og hvem som har hvilket ansvar for dem. 
Ventetiden alene representerer ikke en grense for hva som er forsvarlig pasientbehandling. Det vesentlige er at pasientene blir observert og fulgt opp mens de venter, at personellet har relevant kompetanse og iverksetter hensiktsmessige tiltak i tide. Manglende rutiner og praksis for prioritering og for overvåking $\mathrm{i}$ ventetiden betyr at personalet kan komme til å overse alvorlige lidelser og at pasientbehandlingen ikke kommer i gang til rett tid. I tillegg må virksomheten ha rutiner og praksis for å sikre at beskjeder om det som skjer med pasienten, blir gitt mellom helsepersonellet, og at opplysninger om pasientens tilstand blir notert og dokumentert. Faren for at noen eller noe blir glemt er overhengende dersom ikke slike rutiner er etablert, kjent og blir fulgt i praksis av alt helsepersonell som yter helsehjelp i akuttmottaket. Funn fra tilsynet bekymrer Statens helsetilsyn.

\section{Nok plass i akuttmottaket for å sikre} forsvarlig pasientbehandling

I perioder med stor pågang og opphoping av pasienter mangler mange av akuttmottakene i dette tilsynet nok egnete rom til å gjøre nødvendige undersøkelser og å gi nødvendig behandling og pleie. Dette kan forsinke diagnostikk og oppstart av behandling.

Vi fant at i perioder med opphoping av pasienter foregår undersøkelse og diagnostisering også i korridorer og bak forheng på flersengsrom. I slike situasjoner må sykepleiere og leger i blant velge mellom å bryte taushetsplikten og å gjøre nødvendige undersøkelser. De kan vegre seg for å stille sensitive og nærgående, men nødvendige spørsmål. Pasienten kan på sin side vegre seg for å svare åpent og fullstendig. Manglende mulighet for fortrolig samtale er et brudd på pasientens rett til å få ivaretatt sin integritet $\mathrm{i}$ henhold til pasientrettighetsloven. Konsekvensen er videre at diagnosesetting og beslutninger om å sette i gang behandlingstiltak kan bli tatt på sviktende grunnlag, og under slike omstendigheter er faren for at pasienten kan få feil behandling er så avgjort til stede. Det er alvorlig slik Statens helsetilsyn vurderer det.

\subsection{Kompetansebygging og kompetansestyring for å sikre forsvarlig pasientbehandling}

Personal- og kompetanseressursene skal være underlagt ledelsens styring. Det innebærer at kompetansebehovet skal være definert og at opplærings- og introduksjonsprogrammer skal være etablert, kjent og fulgt for alle som yter helsetjenester i akuttmottaket. Videre skal bemannings- og turnusplanene $\mathrm{i}$ akuttmottaket, og i de avdelingene som er involvert i driften av akuttmottaket, være tilpasset forventet aktivitet enten det er natt, helg, høytid eller ferie; det vil si basert på oversikt over pasientstrømmen i akuttmottaket.

Våre funn tilsier at disse forholdene ikke er tilfredsstillende ivaretatt i foretakene. Vi må derfor kunne si at de fleste akuttmottakene ikke er sikret å ha nødvendig bemanning og kompetanse tilgjengelig for å kunne gi forsvarlig pasientbehandling i perioder med stor trafikk i akuttmottaket.

Nedenfor omtaler vi to sentrale forhold knyttet svikt på dette området. Det ene dreier seg om opplæring av personell, - og da særlig i forhold til de som skal gi legetjenester i akuttmottaket, samt ordninger og praksis for å tilkalle mer erfarne leger når situasjonen tilsier at det er nødvendig. Det andre forholdet er rutiner for tilkalling av ekstraressurser ved aktivitetstopper.

\section{Risiko for svikt i legetjenesten i akutt- mottaket}

Statens helsetilsyn ser alvorlig på at nærmere halvparten av rapportene beskriver mangelfull kompetanse og lite robuste ordninger for å tilkalle leger med mer erfaring og kompetanse til akuttmottakene når det er behov for det. I de fleste akuttmottakene i dette tilsynet var det turnusleger eller nye assistentleger som gjorde de første foreløpige legeundersøkelsene. Når nye leger med ulik kompetanse og erfaring er første lege som møter pasienten, må virksomheten sikre kompetansen gjennom systematiske opplærings- og introduksjonsprogram og fleksible og robuste ordninger med lav terskel for å tilkalle mer erfarne leger. 
Det er derfor alvorlig at flere helseforetak ikke har rutiner og praksis for systematisk opplæring og oppfølging av turnusleger eller assistentleger som er nye i akuttmottaket, verken i forhold til administrative eller medisinske prosedyrer. Selv i helseforetak som har opplæringsplaner både for leger og sykepleiere som skal arbeide i akuttmottaket, blir de ikke alltid fulgt.

Videre varierer det hvor robuste ordninger som etablert for å understøtte nye leger $i$ deres faglige arbeid $i$ akuttmottaket. Det ser ikke ut til å være vanlig praksis i de virksomhetene som er omfattet av dette tilsynet, å bruke helseforetakets samlede legeressurser for å sikre pasientene forsvarlig undersøkelse og behandling i akuttmottaket. Det kan for eksempel dreie seg om å tilkalle hjelp fra anestesilege for smertelindring eller væsketilførsel eller om å få bistand fra en kirurgisk overlege til å prioritere i operasjonsrekkefølgen. Mye tyder også på at terskelen for å tilkalle andre leger, er høy i flere av akuttmottakene i dette tilsynet. Slike terskler kan bero på oppfatninger av at nærmeste overordnede har mange andre gjøremål, at de overordnede sjelden viser spontan interesse for arbeidet i akuttmottaket, at det ikke er etablert rutiner og praksis for å bruke ressurser på tvers av avdelinger og at det ikke er kultur for å be om hjelp "bare" fordi det er travelt.

\section{Risiko for svikt ved behov for ekstra bemanning}

Gjennom rutiner og praksis må det være avklart for alle som arbeider i akuttmottaket, hvem som kan tilkalle hjelp når det er behov for høyere og mer spesialisert kompetanse, og hvem som kan tilkalle ekstra og nødvendig personell ved aktivitetstopper og hverdagskriser, enten det skyldes stor pågang av pasienter eller opphopning av pasienter som venter på overføring til andre avdelinger i sykehuset. I flere av akuttmottakene som var omfattet av dette tilsynet, hadde ikke personalet ens oppfatning av i hvilke situasjoner ekstra ressurser skal tilkalles, eller av hvem som er ansvarlig for å tilkalle.
Konsekvensen av for lite personale eller for lav kompetanse kan bli at undersøkelse og diagnostisering kan være mangelfulle, at de involverte mister oversikten eller gjør feilaktige medisinske vurderinger. 


\section{Statens helsetilsyns oppsummering og anbefalinger}

Statens helsetilsyn er inneforstått med at ledelse, organisering og styring av akuttmottak er en utfordring når aktivitetene i sin natur er uforutsigbare og blir utløst av akutte problemstillinger; noe det kan sies å være vanskelig å "planlegge seg ut av". Vi mener likevel at det er grunnlag for å si at ledelsen i helseforetakene må se nærmere på og vurdere hva den kan sette i gang avstyringsmessige tiltak for å gjøre driftssituasjonen i akuttmottakene mer forutsigbar.

Statens helsetilsyn har gjennom dette tilsynet avdekket at $\mathrm{i}$ perioder når det hoper seg opp med mange pasienter i akuttmottaket samtidig, som enten venter på lege eller på å bli overført til en annen avdeling i sykehuset, er det kompetente enkeltpersoner i akuttmottakene som "bretter opp ermene", improviserer og finner ad hoc-løsninger og redder pressede situasjoner fra å utvikle seg til uønskede hendelser og svikt.

Nå er det ledelsen i helseforetakene som må "brette opp ermene" og sette i verk tiltak som gir mer systematisk og målrettet styring av driften i akuttmottakene, og dermed sikre forsvarlig pasientbehandling til en hver tid.

Avslutningsvis vil vi peke på noen sentrale kjennetegn ved, eller forutsetninger for, systematisk styring og ledelse i helseforetak som sikrer forsvarlig pasientbehandling i akuttmottakene. Statens helsetilsyn anbefaler helseforetakene å gjøre disse kjenne- tegnene til gjenstand for drøfting og vurdering $i$ sin gjennomgang av driften i akuttmottakene.

\section{Ledelsens oppfølging for å sikre forsvarlig drift}

I de fleste helseforetakene i dette tilsynet var administrerende direktør første felles ledelsesnivå i organisasjonen. Arbeidet i akuttmottaket må derfor være underlagt koordinering og styring fra dette nivået. Helseforetaket ledelse må gjøre en systematisk og regelmessig gjennomgang av de har et kvalitetsstyringssystem som sikrer faglig forsvarlig helsetjenester i akuttmottaket. Det kan skje ved hjelp av strategiske møter og/eller ulike rapporteringsformer.

Vanligvis er personell fra flere avdelinger i sykehuset involvert i pasientbehandlingen i akuttmottaket. Det innebærer at ledere på ulike organisatoriske nivåer og i ulike avdelinger skal følge opp driftsresultater i akuttmottaket for å sikre forsvarlige helsetjenester. Dette krever tett dialog, samhandling og koordinering mellom de ulike lederne.

Samlet sett har funn fra dette tilsynet gitt inntrykk av at ledelsen i svært mange av helseforetakene har hatt dårlig oversikt over driften i akuttmottakene. For eksempel ble ikke aktivitetsdata fra akuttmottaket brukt til å overvåke driften eller til å gjøre risikovurderinger. Oversikt over pasientstrømmen ble ikke brukt systematisk av ledelsen for å få kunnskap om når på døgnet, når i uka og når på året arbeids- 
belastningen er særlig stor.

Flere av akuttmottakene hadde ikke et avviksbehandlingssystem som fungerte som forutsatt. Systematisk arbeid med avviksbehandling kan gi ledelsen verdifull informasjon om $i$ sårbare og kritiske deler av driften i akuttmottaket.

Alt dette er informasjon som er relevant og nødvendig for å sikre forsvarlig planlegging og styring av ressursene $\mathrm{i}$ akuttmottaket, og dermed sikre at driften i akuttmottaket er forsvarlig også i travle perioder.

Statens helsetilsyn anbefaler derfor at helseforetakene drøfter og vurdere følgende:

- Hva trenger helseforetaket å sette i gang av aktivitetsregistreringer og andre rapporteringssløyfer for å ha oversikt over driften i akuttmottaket?

- Hvordan sikrer helseforetaket at alt personalet $i$ akuttmottaket har ens forståelse av hva som er avvik og ens praksis for å melde avvik?

- Hvordan sikrer helseforetaket at avviksmeldinger blir oppsummert og brukt i virksomhetens strategiske forbedrings- og utviklingsarbeid?

\section{Risikovurdering og risikostyring}

Ledelsen må sikre en felles forståelse av hvordan situasjoner med overbelastning i akuttmottaket skal håndteres.

Når ledelsen ikke har systematisk oversikt over variasjoner i arbeidsbelastning og aktivitetsnivå i akuttmottaket, har den heller ikke godt nok grunnlag for å vurdere hvilke konsekvenser det kan ha for forsvarlig pasientbehandling at det oppstår flaskehalser i behandlingsforløpet. Slike oversikter er nødvendig for å gjøre seg opp en mening om hva som kan være kritiske trinn i arbeidsprosessene og oppgaveløsningen i akuttmottaket. Dersom ledelsen ikke gjør systematiske risikovurderinger, har den ikke grunnlag for å sette i gang målrettede tiltak og rette opp forholdene slik at faren for svikt blir mindre og pasientsikkerheten blir bedre i akuttmottaket.
Dette tilsynet har avdekket at mange av akuttmottakene manglet "sikkerhetsventiler" eller ordninger for å håndtere pressede situasjoner som oppstår når pasienter blir liggende lenge og vente på legens vurdering eller venter på å bli overført til en annen avdeling i sykehuset. Det dreier seg om ordninger både for å sikre tilstrekkelig medisinskfaglig og nødvendig sykepleiefaglig oppfølging av pasientene når de er $\mathrm{i}$ akuttmottaket. Mye tyder på at i mange av virksomhetene dreier dette seg om "ukultur" som hindrer turnusleger og andre leger som er nye i akuttmottaket, fra å tilkalle hjelp av mer erfarne leger når de står fast $\mathrm{i}$ faglige vurderinger eller når det hoper seg opp med mange pasienter samtidig. På samme måte synes det ikke å være vanlig praksis at personalet i akuttmottaket tilkaller ekstra hjelp fra andre avdelinger i sykehuset dersom det er behov for flere hender til pleiefaglig oppfølging av pasienter som venter.

Statens helsetilsyn anbefaler derfor at helseforetakene drofter og vurderer følgende:

- Hvordan motvirker helseforetaket en kultur som hindrer leger "som er nye på stedet" fra å tilkalle mer erfarne leger for å bistå i undersøkelse av pasientene i akuttmottaket?

- Hvilke ordninger har helseforetaket etablert for å sikre at det er enkelt å tilkalle ekstra hjelp fra andre avdelinger ved aktivitetstopper i akuttmottaket? 


\title{
"DAN BOTTA GO VUORDIT ...." - bealuštahtti divššohasmeannudeapmi fáhkkadustehusas?
}

\author{
Riikkaviidosaš geahču čoahkkáigeassu fáhkkadustehusaid \\ dohkálašvuoða ja kvalitehta hárrái somáhtalaš \\ spesialistadearvvašvuoðabálvalusas
}

Dearvvašvuoðageahču Raportta 2/2008 čoahkkáigeassu

Fylkkaid dearvvašvuođageahčču čađahii 2007:s geahču 27 riikka 54 fáhkkadustehusaid dohkálašvuođas ja kvalitehtas somáhtalaš spesialistadearvv ašvuođabálvalusa oktavuođas.

Dearvvašvuođadoaimmahaga jođiheamis lea ovddasvástádus sihkkarastit ahte beaivválaš barggut plánejuvvojit, organiserejuvvojit, čađahuvvojit ja buoriduvvojit dearvvašvuođalágaid gáibádusaid mielde. Dat lea eaktun jus divššohasa dusten, vuoruheapmi, iskan, diagnostiseren, goziheapmi ja dálkkodeapmi fáhkkadustehusain galggaš šaddat fágalaččat bealuštahttin. Riikkaviidosaš geahču ulbmil lei iskat nagodit go dearvvašvuođadoaimmahagat fuolahit iežaset ovddasvástádusa ja movt dat dan dahket.

Stáhta dearvvašvuođageahčču lea oppalaččat gávnnahan ahte dáid fáhkkadustehusaid árgabeaivvis lea váilevaš stivren ja jođiheapmi. Eanas fáhkkadustehusain mat ledje geahčus mielde, lea beaivválaš doaibma dávjá dan duohken ahte gelbbolaš ovttaskas olbmot "máhcastit sojiid" ja rahčet gávdnat čovdosiid váttis dilálašvuođaide, árgabeaiváttisvuođaide ja bohtalčottačuolmmaide. Orru leame dáhpin ahte gaskaboddosaš čovdosat, ii ge vuogádatlaš stivren, eastadit váttis dilálašvuođaid šaddamis vahágis dáhpáhussan ja váilevašvuohtan. 


\section{"While we are waiting...." - do patients receive ade- quate treatment in accident and emergency units? Summary of countrywide supervision in 2007 of accident and emergency units in specialized health services - are services of adequate quality and do they meet legislative requirements?}

Short summary of Report from the Norwegian Board of Health Supervision 2/2008

In 2007 the Norwegian Board of Health Supervision in the Counties carried out supervision of 27 of the 54 accident and emergency services within specialized health services in Norway. The theme of supervision was whether the quality of these services is adequate, and whether these services are provided in accordance with legislative requirements.

The management of the health trusts have responsibility for ensuring that daily tasks are planned, organized, carried out and improved in accordance with legislative requirements.

Reception, prioritization, examination, diagnosis, monitoring and treatment of patients in accident and emergency units shall be in line with sound professional standards. The main aim supervision of these services was to investigate whether health trusts fulfil their responsibilities, and how they do this.

The Norwegian Board of Health Supervision has found that, in general, inadequate management and leadership affects the day-to-day running of these services. In most of the accident and emergency units where supervision was carried out, much of the day-to-day activities depended on competent individuals who "rolled up their sleeves" and stretched themselves to the limit to find solutions to problems related to awkward situations, everyday crises and bottlenecks in the system. The general picture seems to be that ad-hoc solutions rather than systematic man- agement prevent stressful situations from developing into adverse events and deficiencies in the services. 


\section{Rapport fra Helsetilsynet}

Utgivelser 2007

1/2007 Meldesentralen - årsrapport 2005

2/2007 "Kjem du levande inn, kjem du levande ut" - men kva skjer så? Oppfølgingstilbodet etter ei alkoholforgifting

3/2007 Oppsummering av landsomfattende tilsyn i 2006 med tverrfaglige spesialiserte tjenester til rusmiddelmisbrukere

4/2007 Ikkje likeverdige habiliteringstenester til barn. Oppsummering av landsomfattande tilsyn med habiliteringstenester til barn 2006

5/2007 Rettssikkerhet for utviklingshemmede, II. Oppsummering av landsomfattende tilsyn i 2006 med rettssikkerhet knyttet til bruk av tvang og makt overfor personer med psykisk utviklingshemning

6/2007 Klager på økonomisk stønad. En analyse av fylkesmennenes klagesaksbehandling etter kapittel $5 \mathrm{i}$ sosialtjenesteloven for årene 1995-2005

7/2007 Klagesaker etter sosialtjenesteloven 2006 sammenstilling av fylkesmennenes rapportering

8/2007 Tjenestetilbudet til personer med psykiske lidelser

Alle utgivelsene i serien finnes i fulltekst på Helsetilsynets nettsted www.helsetilsynet.no.

Enkelte utgivelser finnes i tillegg i trykt utgave som kan bestilles fra Helsetilsynet, Postboks 8128 Dep, 0032 Oslo, tlf. 215299 00, faks 215299 99, e-post postmottak@helsetilsynet.no.

\section{Utgivelser 2008}

1/2008 Meldesentralen - årsrapport 2006

2/2008 "Mens vi venter ..." - forsvarlig pasientbehandling i akuttmottakene? Oppsummering av landsomfattende tilsyn i 2007 med forsvarlighet og kvalitet i akuttmottak i somatisk spesialisthelsetjeneste.

\section{Tilsynsmeldinger}

Tilsynsmelding er en årlig publikasjon fra Helsetilsynet. Den benyttes til å orientere omverdenen om saker som er sentrale for sosial- og helsetjenestene og for offentlig debatt om tjenestene.

Tilsynsmeldinger fra og med 1997 finnes i fulltekst på www.helsetilsynet.no. De nyeste kan også bestilles i trykt utgave. 


\section{OPPSUMMERING}

\section{HELSETILSWnET}

Rapport fra Helsetilsynet 2/2008

\section{"MENS VI VENTER ..." - forsvarlig pasientbehandling i akuttmottakene? Oppsummering av landsomfattende tilsyn i 2007 med forsvarlighet og kvalitet i akuttmottak i somatisk spesialisthelsetjeneste}

Helsetilsynet i fylkene gjennomførte i 2007 tilsyn med forsvarlighet og kvalitet i 27 av landets 54 akuttmottak i somatisk spesialisthelsetjeneste.

Ledelsen i helseforetaket har ansvar for å sikre at daglige arbeidsoppgaver blir planlagt, organisert, utført og forbedret i samsvar med krav i helselovgivningen. Det er en forutsetning for at mottak, prioritering, undersøkelse, diagnostisering, overvåking og behandling av pasienter i akuttmottak skal være faglig forsvarlig. Hovedmålet med dette landsomfattende tilsynet var å undersøke om og hvordan helseforetakene ivaretar ansvaret sitt.

Statens helsetilsyn har funnet et totalbilde som viser at mangelfull styring og ledelse preger hverdagen i disse akuttmottakene. I de fleste av akuttmottakene som er omfattet av tilsynet, henger for mye av den daglige driften på at kompetente enkeltpersoner i akuttmottaket "bretter opp ermene" og strekker seg svært langt for å løse kinkige situasjoner, hverdagskriser og flaskehalsproblematikk. Det synes å være et mønster at ad hoc-løsninger snarere enn systematisk styring redder pressede situasjoner fra å utvikle seg til uønskede hendelser og svikt. 